\title{
Genetic Variability Studies for Different Attributes in Carrot Genotypes (Daucus carota L.) under Kharif Season
}

\section{J.R. Meghashree*, C.N. Hanchinamani, H.P. Hadimani, Sandhyarani Nishani, S.H. Ramanagouda and Chandrakant Kamble}

\author{
Department of Vegetable Science, K. R. C. College of Horticulture, \\ Arabhavi - 591 218, Karnataka, India \\ *Corresponding author
}

\section{A B S T R A C T}

\section{Keywords \\ Daucus carota, \\ Genotypic coefficient of \\ variation $(\mathrm{GCV})$, \\ Phenotypic coefficient of \\ variation $(\mathrm{PCV})$, \\ Heritability, Genetic \\ advance over mean and \\ genotypes \\ Article Info \\ Accepted: \\ 24 August 2018 \\ Available Online: \\ 10 December 2018}

Twenty five genotypes of carrot were evaluated for different traits in a randomized complete block design with two replications. The variation was observed for all the parameters studied. Root weight, root/top length ratio, total yield/plot, total yield/ha, cortex thickness, TSS, $\beta$-carotene content, ascorbic acid content, total phenol, protein, root forking and root splitting showed high genotypic coefficient of variation and phenotypic coefficient of variation. High heritability was observed for all the characters except number of leaves/plant, petiole length, root diameter, root length and days to first root harvest. High genetic advance over mean was observed for all the characters except number of leaves/plant, petiole thickness, root diameter, root length and days to first root harvest.

\section{Introduction}

Carrot (Daucus carota L.) is most important root crop worldwide nutritionally and belongs to the family Umbelliferae (Apiaceae) with chromosome number $2 \mathrm{n}=18$. Carrot is originated from Southwestern Asia, especially Afghanistan (Banga, 1976).

It is a popular cool season vegetable. In temperate region, it is cultivated during spring and summer season, while in tropical region during winter season. It is grown as biennial for seed production and annual for its roots.
In India, carrot is mainly cultivated in the states of Haryana, Punjab, Uttar Pradesh, Karnataka and Tamil Nadu. In Karnataka, carrot is mainly cultivated in the districts of Kolar, Chikkaballapur, Belagavi, Bengaluru Rural, Gulbarga and Bidar. The ideal quality root should have minimum core, maximum cortex and a minimum difference between the colour intensities of these tissues. The carrot is used for salad and as cooked vegetable. It is used for making fermented product Kanji. Carrot seeds are used for flavouring. The colour is extracted and used for colouring foods. The gajarhalwa, pickles, soups, sweet 
meat, pies and preserves are prepared from the tender roots. It is used to cure ulcers, burns, scalds and jaundice (Rana, 2008).

To formulate effective breeding programme, the critical assessment of nature and magnitude of variability in the germplasm stock is one of the important pre-requisite (Janaki et al., 2015). The magnitude of genetic variability present in germplasm is proportional to the crop improvement. Greater variability affords the greater chances for effective selection for desirable types (Vavilov, 1951). The variability, heritability and genetic advance were relative measures of the efficiency of selection of genotype from a highly variable population based on phenotype (Santhi et al., 2015). Heritability was an indicator for measuring the relative influence of environment on expression of genotypes (Jain et al., 2010). Heritability along with genetic advance was the genetic gain expected from selection (Johnson et al., 1955). Keeping in view the above points as land marks, the present investigation was conducted.

\section{Materials and Methods}

The present investigation was carried out during the kharif season, 2017-18 at Kittur Rani Channamma College of Horticulture, Arabhavi, Belagavi district (Karnataka). The details of the experiment, materials used and methodology followed during the course of investigation were described below. Twenty five genotypes of carrot collected from different sources including one recommended variety Hisar Gairic as check were used for the present experiment. Details of the genotypes used in the study were presented in Table 1. The experiment was laid out in randomized complete block design (RCBD) with two replications. Between the rows, a distance of $30 \mathrm{~cm}$ was maintained and $10 \mathrm{~cm}$ between the plants within the each plot. The standard package of practice was followed for raising the crop. The observations on various parameters were recorded from five randomly selected plants for each treatment in each replication. The mean values of various parameters were subjected to analysis of variance as described by Gomez and Gomez (1983). Statistical analyses were carried out using INDOSTAT software. The magnitude of variation present in a parameter both genotypically and phenotypically were calculated based on the value of genotypic and phenotypic variance according to Burton and Devane (1953). The broad sense heritability was calculated as the ratio of genotypic variance to the phenotypic variance and expressed in percentage (Falconer, 1981) and categorized into different scales according to Searle (1965). The ratio of genetic advance over population general mean as percentage was worked out according to Johnson et al., (1955).

\section{Results and Discussion}

The components of genetic parameters for yield and its attributes exhibited a wide range of variability for the parameters studied. The values of phenotypic co-efficient of variation were of higher in magnitude than that of genotypic co-efficient of variation for all the characters indicating that the environment played an important role in influencing the expression of the traits. The heritability was worked out for all the traits by the variance components. Genetic gain was computed to accomplish the comparison of the traits in relation to environment. The variability parameters of all the genotypes were furnished here under Table 2.

High genotypic coefficient of variation was noticed for root weight, root/top length ratio, total yield/plot, total yield/ha, cortex thickness, TSS, $\beta$-carotene content, ascorbic acid content, total phenol, protein, root forking and root splitting. The simple selection was 
highly effective for further improvement and no wide difference between PCV and GCV was observed among all the characters. Plant height at 60 DAS, plant height at harvest, petiole length, leaf length, core diameter, core thickness, total sugars and reducing sugars exhibited moderate estimates of GCV. The reasonable amount of variability was found and can be used in further crop improvement. GCV was noted low for number of leaves/plant, petiole thickness, root diameter, root length and days to first root harvest. This indicates that, there was a less chance of improving these traits by direct visual selection. These results were also noticed by previous researchers such as Dod et al., (2013), Prajapati et al., (2014), Sivathanu et al., (2014), Mallikarjunarao et al., (2015), Priya and Santhi (2015), Nagar et al., (2016) and Teli et al.,(2017).

Plant height at $60 \mathrm{DAS}$, petiole length, root weight, root/top length ratio, total yield/plot, total yield/ha, cortex thickness, TSS, $\beta$ carotene content, ascorbic acid content, total phenol, protein, root forking and root splitting showed high phenotypic coefficient of variation.

Table.1 List of genotypes with their sources used in the experiment

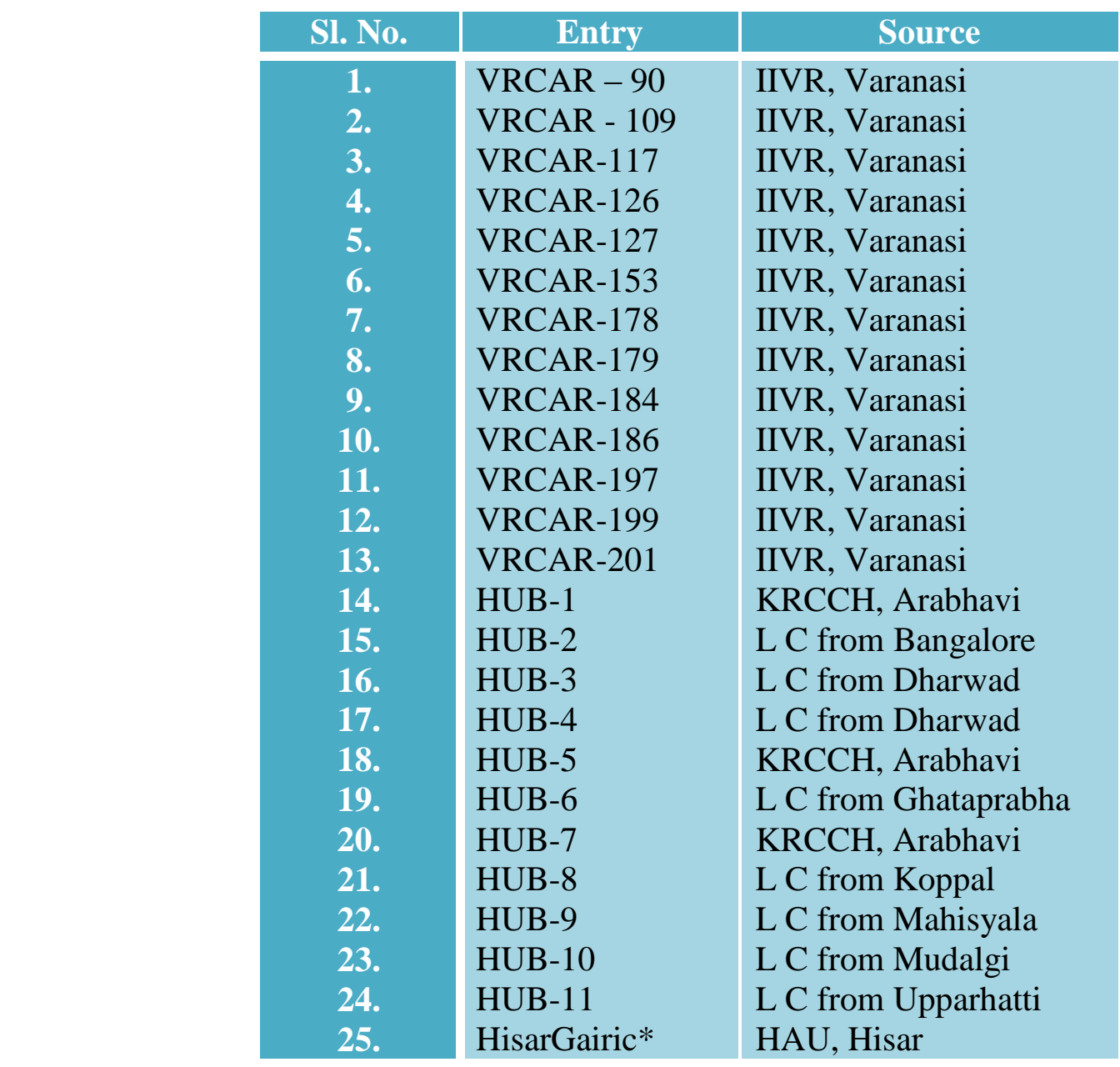

*Check cultivar

HAU: Hisar Agriculture University, Hisar, Haryana

IIVR: Indian Institute of Vegetable Science, Varanasi, UP 
Table.2 Estimates of mean, range, components of variance, heritability and genetic advance for growth, yield and quality parameters in carrot (Kharif season)

\begin{tabular}{|c|c|c|c|c|c|c|c|}
\hline $\begin{array}{l}\text { SI. } \\
\text { No. }\end{array}$ & Character & Range & Mean & GCV $(\%)$ & $\operatorname{PCV}(\%)$ & $h^{2}(\%)$ & GAM (\%) \\
\hline A. & \multicolumn{7}{|l|}{ Growth parameters } \\
\hline 1. & Plant height at 60 DAS $(\mathrm{cm})$ & $31.55-75.75$ & 52.82 & 18.02 & 21.05 & 73.31 & 31.79 \\
\hline 2. & Plant height at harvest $(\mathrm{cm})$ & $45.65-85.80$ & 64.60 & 12.99 & 14.77 & 77.35 & 23.54 \\
\hline 3. & Number of leaves per plant & $8.30-12.20$ & 10.88 & 6.36 & 9.33 & 46.46 & 8.93 \\
\hline 4. & Petiole thickness (mm) & $1.36-2.12$ & 1.66 & 8.29 & 9.70 & 73.04 & 14.59 \\
\hline 5. & Petiole length $(\mathrm{cm})$ & $14.22-26.79$ & 20.96 & 14.09 & 20.12 & 49.00 & 20.31 \\
\hline 6. & Leaf length $(\mathrm{cm})$ & $18.21-36.75$ & 28.69 & 15.61 & 17.45 & 80.05 & 28.78 \\
\hline B. & \multicolumn{7}{|l|}{ Yield parameters } \\
\hline 7. & Root weight (g) & $22.03-56.91$ & 36.82 & 23.47 & 24.53 & 91.52 & 46.25 \\
\hline 8. & Root diameter $(\mathrm{cm})$ & $2.01-3.61$ & 2.88 & 9.70 & 12.79 & 57.57 & 15.17 \\
\hline 9. & Root length $(\mathrm{cm})$ & $11.02-17.94$ & 13.83 & 9.87 & 15.21 & 42.15 & 13.20 \\
\hline 10. & Core diameter (mm) & $11.28-20.43$ & 15.88 & 14.47 & 16.01 & 81.72 & 26.96 \\
\hline 11. & Root /top length ratio & $0.35-0.82$ & 0.50 & 20.95 & 26.53 & 62.39 & 34.10 \\
\hline 12. & Days to first root harvest & $99.00-108.00$ & 103.70 & 1.78 & 2.32 & 58.99 & 2.82 \\
\hline 13. & Total yield per plot (kg) & $3.30-8.53$ & 5.52 & 23.47 & 24.53 & 91.53 & 46.25 \\
\hline 14. & Total yield per hectare $(\mathrm{t})$ & $7.34-18.97$ & 12.27 & 23.46 & 24.52 & 91.53 & 46.24 \\
\hline
\end{tabular}

GCV = Genotypic co-efficient of variation PCV = Phenotypic co-efficient of variation

DAS = Days after sowing $\mathbf{h}^{2}=$ Heritability (broad sense)

$\mathrm{GAM}=$ Genetic advance over mean 


\begin{tabular}{|c|c|c|c|c|c|c|c|}
\hline \multirow{2}{*}{$\begin{array}{l}\text { Sl. } \\
\text { No. }\end{array}$} & & & & & & & Contd... \\
\hline & Character & Range & Mean & GCV $(\%)$ & $\operatorname{PCV}(\%)$ & $\mathbf{h}^{2}(\%)$ & GAM (\%) \\
\hline & Biophysical parameters & & & & & & \\
\hline 15. & Core thickness (mm) & $6.25-10.87$ & 8.33 & 15.81 & 17.66 & 80.12 & 29.15 \\
\hline 16. & Cortex thickness (mm) & $3.22-8.36$ & 5.60 & 21.37 & 22.19 & 92.75 & 42.41 \\
\hline C. & \multicolumn{7}{|l|}{ Quality parameters } \\
\hline 17. & TSS ( ${ }^{\circ}$ Brix $)$ & $3.95-8.55$ & 5.70 & 21.90 & 22.22 & 97.15 & 44.48 \\
\hline 18. & $\beta$-carotene content $(\mu \mathrm{g} / 100 \mathrm{~g})$ & $1640.0-3918.0$ & 2358.52 & 26.44 & 26.75 & 97.68 & 53.83 \\
\hline 19. & Total sugars $(\%)$ & $2.31-3.83$ & 2.93 & 11.72 & 12.54 & 87.35 & 22.57 \\
\hline \multirow[t]{2}{*}{20.} & Ascorbic acid content (mg/100 g) & $1.25-5.02$ & 2.80 & 41.64 & 41.73 & 99.56 & 85.59 \\
\hline & Biochemical parameters & & & & & & \\
\hline 21. & Total phenol (mg/100 g) & $3.13-10.10$ & 6.29 & 29.13 & 29.28 & 98.95 & 59.69 \\
\hline 22. & Protein $(\%)$ & $0.24-0.70$ & 0.42 & 25.70 & 25.96 & 97.94 & 52.39 \\
\hline 23. & Reducing sugars (\%) & $1.27-2.81$ & 1.88 & 19.10 & 19.71 & 93.94 & 38.15 \\
\hline D. & \multicolumn{7}{|l|}{ Physiological disorders } \\
\hline 24. & Root forking (\%) & $0.29-4.49$ & 2.90 & 34.87 & 35.17 & 98.26 & 71.20 \\
\hline 25. & Root splitting (\%) & $0.00-4.59$ & 2.77 & 49.24 & 49.46 & 99.11 & 100.99 \\
\hline
\end{tabular}


Since, narrow differences were observed between GCV and PCV indicated that the selection was an effective tool to improve these traits. Moderate estimates of PCV were exhibited by plant height at harvest, leaf length, root diameter, root length, core diameter, core thickness, total sugars and reducing sugars. Number of leaves/plant, petiole thickness and days to first root harvest exhibited low PCV values. This indicates that, there was a less chance of improving these parameters by direct selection. These results were in line with Naseeruddin et al., (2011), Kumar et al., (2012), Dod et al., (2013), Sivathanu et al.,(2014), Mallikarjunarao et al., (2015), Priya and Santhi (2015), Dhillon et al., (2016) and Teli et al.,(2017).

Heritability was recorded high for plant height at 60 DAS, plant height at harvest, petiole thickness, leaf length, root weight, core diameter, root/top length ratio, total yield/plot, total yield/ha, core thickness, cortex thickness, TSS, $\beta$-carotene content, total sugars, ascorbic acid content, total phenol, protein, reducing sugars, root forking and root splitting. High heritability indicates less influence of environment and controlled by additive gene action. The selection was easy for all these traits. Number of leaves/plant, petiole length, root diameter, root length and days to first root harvest showed moderate heritability. These traits were accountable to considerable influence by extraneous factors. This result is compliance with earlier researchers like Yadav et al., (2009), Jain et al., (2010), Amin and Singla (2010), Naseeruddin et al., (2011), Gupta et al., (2012), Sivathanu et al., (2014), Prajapati et al., (2014), Priya and Santhi (2015), Mallikarjunarao et al., (2015) and Teli et al., (2017).

High genetic advance was recorded for plant height at 60 DAS, plant height at harvest, petiole length, leaf length, root weight, core diameter, root/top length ratio, total yield/plot, total yield/ha, core thickness, cortex thickness, TSS, $\beta$-carotene content, total sugars, ascorbic acid content, total phenol, protein, reducing sugars, root forking and root splitting. Additive gene was controlling all these traits and made them to respond better for selection. These traits were least influenced by environmental factors and respond effectively for selection.Petiole thickness, root diameter and root length exhibited moderate estimates of genetic advance.The variability in these traits was due to both additive and non-additive gene action. Selection based on these traits was less effective in breeding programme. Number of leaves/plant and days to first root harvest recorded low genetic advance. These characters were governed by non-additive gene action and selection based on these parameters found not effective. The findings were similar to other studies of Gupta et al., (2012), Kumar et al., (2012), Asima et al., (2013),Sivathanu et al., (2014), Mallikarjunarao et al., (2015), Datta et al., (2015) and Teli et al., (2017).

Thus, there was variation available among the traits, which can be exploited by selection or hybridization. Hence, due consideration to be given to diversity of these traits in future for improvement of yield. High GCV and PCV indicate that, there will be wide genetic base for future crop improvement programme. High heritability with genetic gain implies that, selection was effective to bring genetic improvement as traits controlled by additive gene action.

\section{References}

Amin, A. and Singla, J., 2010, Genetic variability, heritability and genetic advance studies in carrot (Daucus carota var. sativa L.). Electronic 
Journal of Plant Breeding, 1(6): 15041508.

Asima, A., Kumar, S.P. and Parveen, W.K., 2013, Genotypic variation for quantitative and qualitative traits in Asiatic and European carrot (DaucuscarotaL.var. sativa).Indian Journal of Plant Genetic Resources, 26(2): 151-154.

Banga, O., 1976, Carrot (Daucus carota L.) (Umbelliferae). In Evolution of crop plants, Simmond, N. W., (Eds) Longman Inc., New York, USA, pp. 291-293.

Burton, G. W. and Devane, E. M., 1953, Estimating heritability in tall fescue (Festuca arundinacea) from replicated clonal material. Agronomy Journal, 45(3): 478-481.

Datta, S., Mal, D. and Nimbalkar, K.H., 2015, Performance and variability studies of radish (Raphanus sativus L.) variety under Terai Zone of West Bengal. Green Farming, 6(6): 1269-1272.

Dhillon, H.S., Dhillon, T.S. and Devi, R., 2016, Quality characterization in carrot (Daucus carota L.) germplasm. Indian Journal of Ecology, 43(1).

Dod, V. N., Kale, V. S., Nagare, P. K. and Wagh, A. P., 2013, Genetic variability and correlation studies in carrot (Daucus carrota L.). In: National Symposium on Abiotic and Biotic Stress Management in Vegetable crops held on $9^{\text {th }}$ April, 2013 at IIVR, Varanasi, India, 3: 32-33

Falconer, D. S., 1981, Introduction to quantitative Genetics, $2^{\text {nd }}$ Edition, Oliver and Boyd, Edinburg, London, pp. 164-176.

Gomez, K. A. and Gomez, A. A., 1983, Statistical Procedures for Agricultural Research.John Wiley and Sons Inc., New York, pp. 357-427.

Gupta, A.J., Verma, T. S., Bhat, R. and Mufti, S., 2012, Studies on genetic variability and character association in temperate carrot.Indian Journal of Horticulture, 69(1): 75-78.

Jain, Y. P., Dod, V.N., Nagare, P.K. and Kale, V.S., 2010, Genetic variability in carrot (Daucus carota L.). Asian Journal of Horticulture, 5(2): 514-516.

Janaki, M., Naidu, L. N., Ramana, C. V. and Rao, M.P., 2015, Assessment of genetic variability, heritability and genetic advance for quantitative traits in chilli (Capsicum annuиm L.). The Bioscan, 10(2): 729-733.

Johnson, H.W., Robinson, H. F. and Comstock, R.E., 1955, Genotypic and phenotypic correlations in soyabean and their implications in selection. Agronomy Journal, 47(7): 477-483.

Kumar, R., Sharma, R., Gupta, R. K. and Singh, M., 2012, Determination of genetic variability and divergence for root yield and quality characters in temperate radishes. International Journal of Vegetable Science, 18: 307318.

Mallikarjunarao, K., Singh, P.K., Vaidya, A., Pradhan, R. and Das, R.K., 2015, Genetic variability and selection parameters for different genotypes of radish (Raphanus sativus L.) under Kashmir valley.Ecology, Environment and Conservation, 21(4): 361-364.

Nagar, S. K., Paliwal, A., Tiwari, D., Upadhyay, S. and Bahuguna, P., 2016, Genetic variability, correlation and path study in radish (Raphanus sativus L.) under near temperate conditions of Garhwal hills. International Journal for Scientific Research and Development, 4(9): 174-176.

Naseeruddin, K., Pant, S. C., Tomar, Y. K. and Rana, D. K., 2011, Genetic variability and selection parameters for different genotypes of radish (Raphanus sativus L.) under valley condition of 
Uttarakhand. Progressive Horticulture, 43(2): 256- 258.

Prajapati, A., Tank, C.J., Gami, R.A., Ravindrababu, Y. and Chauhan, R.M., 2014, Genetic variability in carrot (Daucus carota L.) under different environments. GAU Research Journal, 39(2): 102-108.

Priya, P.A. and Santhi, V.P., 2015, Variability, character association and path analysis for yield and yield attributes in carrot (Daucus carota L.). Electronic Journal of Plant Breeding, 6(3): 861-865.

Rana, M. K., 2008, Olericulture in India. Kalyani Publishers, New Delhi, pp. 336-363.

Santhi, V.P., Priya, P.A., Anita, B. and Selvaraj, N., 2015, Geneticvariability, heritability and genetic advance in varieties of carrot (Daucus carota L.). International Journal of Plant Sciences, 10(2): 136-141.
Searle, S. R., 1965. The value of indirect selection in mass selection. Biometrics, 21: 682-707.

Sivathanu, S., Yassin, G.M. and Kumar, S.R., 2014, Seasonal effect on variability and trait relationship in radish. Research in Environment and Life Sciences, 7(4): 275- 278.

Teli, S.K., Kaushik, R.A., Ameta, K.D., Kapuriya, V.K., Mali, D. and Teli, L.K., 2017, Genetic variability, heritability and genetic advance in carrot (Daucus carota var. sativa L.). International Journal of Current Microbiology and Applied Sciences, 6(5): 2336-2342.

Vavilov, N.I., 1951, The Origin, variation, immunity and breeding of cultivated plants. Chronica Botanica, 13: 4-364.

Yadav, M., Snigdha, T., Singh, D.B., Rashmi, C., Roshan, R.K. and Nongallei, P., 2009, Genetic variability, correlation coefficient and path analysis in carrot. Indian Journal of Horticulture, 66(3): 315-318.

\section{How to cite this article:}

Meghashree, J.R., C.N. Hanchinamani, H.P. Hadimani, Sandhyarani Nishani, S.H. Ramanagouda and Chandrakant Kamble. 2018. Genetic Variability Studies for Different Attributes in Carrot Genotypes (Daucus carota L.) under Kharif Season. Int.J.Curr.Microbiol.App.Sci. 7(12): 3419-3426. doi: https://doi.org/10.20546/ijcmas.2018.712.391 